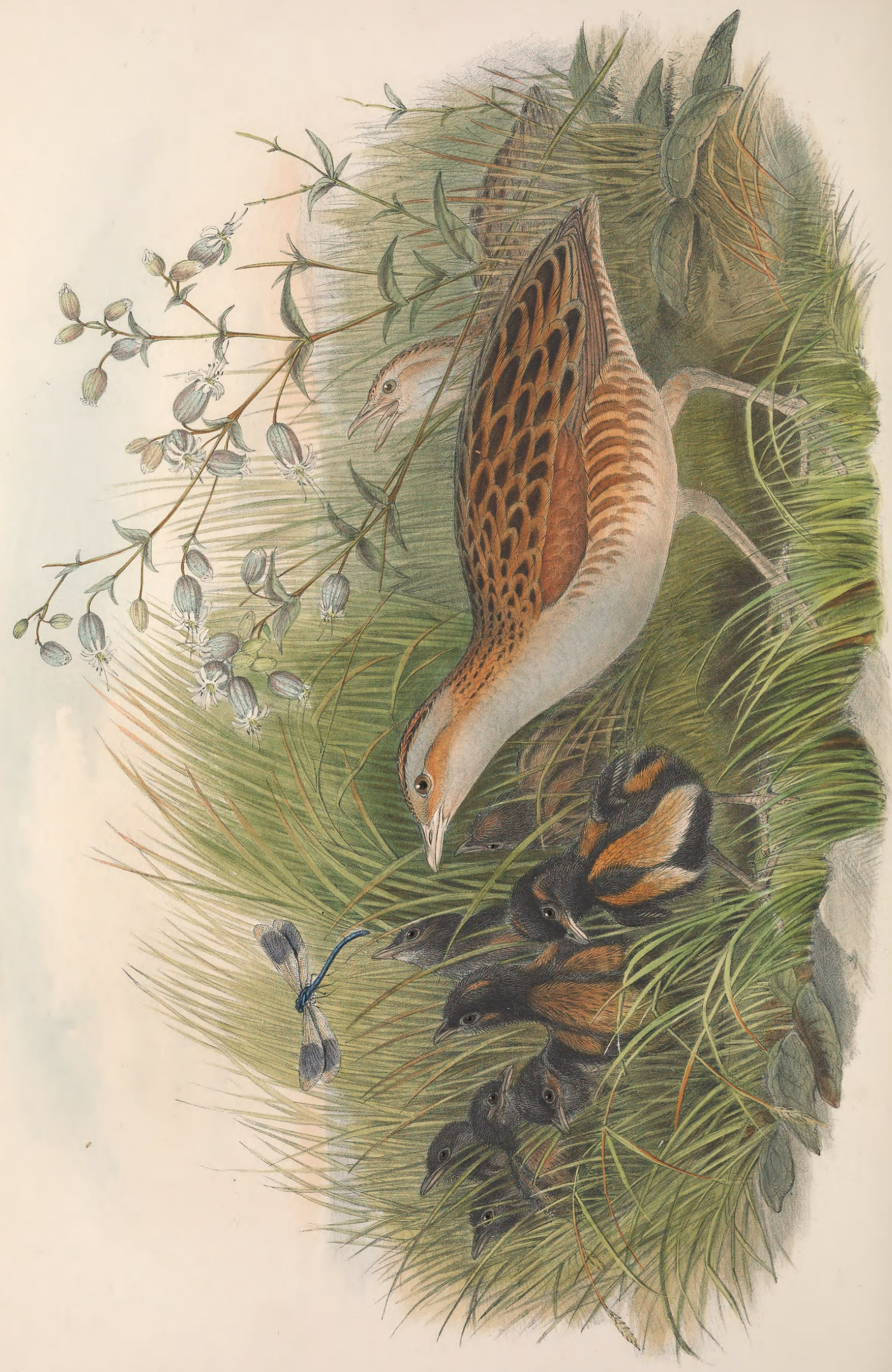




\title{
CREX PRA'TENSIS.
}

\author{
Land-Rail, or Corn-Crake.
}

Rallus Crex, Linn. Syst. Nat., tom. i. p. 261.

Porphyrio rufescens, Briss. Orn., tom. v. p. 533.

Gallinula Crex, Lath. Ind. Orn., vol, ii. p. 766.

Crex pratensis, Bechst. Naturg. Deutsch., tom. iv. p. 470.

Ortygometra Crex, Steph. Cont. of Shaw's Gen. Zool., vol. xii. p. 213, pl. 26.

There are doubtless many persons, with a taste for the natural objects around them, who are not aware that our avifauna is composed of birds which are stationary, as the Robin and the Wren, chance visitors, like the Hoopoe and the Oriole, spring migrants, like the Swallow and the Cuckoo, and autumn migrants, like the Fieldfare and the Redwing. The autumnal visitors which come from colder climates, such as Norway and Sweden, retire northward again about the time when our spring visitors arrive from Africa: these latter comprise, beside the Swallow and smaller sylvan species, the Saxicoline, the Cuckoo, the Quail, the Night-Jar, Wryneck, Land-Rail, \&c.,- the aggregate being about fifty species. Thus, when we lose our winter visitants, their place is supplied by the arrival, during the month of April, of fifty kinds of birds which had wintered elsewhere. No one of these spring visitors is more conspicuous than the Land-Rail, which, arriving about the second week in April, gradually spreads over the whole of the British Islands, and by the 1st of May is as common in Sutherlandshire as it is in our most southern counties; in Ireland the movement is precisely similar, and it is even more numerous there than in England. Britain is by no means the most northern country which the Land-Rail annually visits; for in summer it is found, but in smaller numbers, in Iceland and Greenland. Independently of the localities above mentioned, the Land-Rail is found all over Europe, from north to south; and in one or other part of the year, from Madeira in the Atlantic, throughout Northern Africa, Asia Minor, and as far eastward as Affghanistan.

Soon after its arrival in spring, this restless migrant settles itself in some low grassy mead, field of clover or corn, or bed of osiers, and the male commences the harsh, kraking, monotonous call so well known to every one resident in the country. As soon as the female has responded to the invitation, the mated pair commence their nest; the due number of eggs having been laid in daily succession, the task of incubation is commenced; and by the time the grass is ready for the scythe, the mead bespangled with the buttercup, and the charlock well in flower, the hatching-time has arrived, and the coal-black young are following their parents stealthily through the grass. These active little creatures must grow with unusual rapidity; for the barley is scarcely ripe before they can fly, and the lst of September is usually too late for the sportsman to benefit by more than a remnant of the thousands that must have been bred in our islands. The great mass of both old and young are now near the south coast, waiting for the first favourable opportunity to cross the water, and gradually pass southward to their winter quarters. It is true that Land-Rails are often killed in September, and even in October. A field of standing clover will even hold them longer; and some few must stay with us the whole winter, for specimens are frequently seen in the London markets at Christmas, and I once picked up a dead Land-Rail, at Hawkstone, in January, which had apparently been killed by some bird of prey. But, as I have stated, the greater number depart in September-a circumstance very much to be regretted by those who are fond of sport, or who possess an epicurean taste; for there are few birds better adapted to gratify it, and still fewer that are its equal. How stealthily does the Land-Rail thread the grass, the corn, or the standing clover! With what command does it utter its harsh call so as to deceive those who may be anxiously wishing to sight it ! at one moment the noise seems to be at your feet; at the next it appears to be many yards distant, and so perhaps it is ; yet the boy, sitting in yonder ditch, with the aid of a comb and a piece of wood, calls the bird within a yard of him, and with uplifted stick strikes the moving grass and secures it. In the neighbourhood of London, where all is grass and dairy farms, $\mathrm{Mr}$. Bond tells me, many are destroyed in this way.

With regard to the flight of the Land-Rail, every sportsman will testify that it is the most laboured, the slowest, and the straightest of all birds'; yet, to our astonishment, we know that this species crosses wide seas, and performs a migration of greater extent than any other of our spring birds, with the exception, perhaps, of the Wheatear. We cannot but wonder how it can fly so great a distance without exhaustion, when to cross only a moderately-sized field seems to tire it when flushed by the dogs in the sporting-season; for it invariably drops within a hundred yards, and very rarely is it forced to rise again. On my outward voyage to America a Land-Rail visited the ship when we were more than two 
hundred miles from the coast of Ireland, and, after flying round the vessel two or three times, settled on the rigging. I tried in vain to catch it, and it flew to sea again in half an hour, winging its way I know not whither. On this subject I find the following passage in the 'Field' of November the 10th, 1860 :"In October 1857, I was travelling up the Mediterranean; and between Gibraltar and Malta, Land-Rails frequently came on board, flying south, particularly near the Algerian and Tunisian coasts, and I think one or two after we left Malta; so that if the Land-Rail does not migrate from England, it is not from want of the capability of doing so, and its migration in the south of Europe renders it probable that it does the same in the north. (B. L. C.)"

So many instances have been recorded of this bird assuming the semblance of death as a means of escape from impending danger, that there seems every reason to believe it really does resort to this artifice when occasien requires. My good old friend Edward Jesse, Esq., mentions, in his 'Gleanings in Natural History,' that " A gentleman had a Corn-Crake brought to him by his dog, to all appearance quite dead. As it lay on the ground, he turned it over with his foot, and felt convinced that it was dead. Standing by, however, in silence, he suddenly saw it open an eye; he then took it up, its head fell, its legs hung, and it appeared again quite dead. He then put it in his pocket, and before long felt it all alive, and struggling to escape. He then took it out; it was as lifeless as before. Having laid it again upon the ground, and retired to some distance, the bird in about five minutes warily raised its head, looked round, and decamped at full speed." A similar instance of its feigning death was communicated to the Rev. F. O. Morris, by W. R. Shepherd, Esq., of the Dana, Shrewsbury. "Whilst out with my gun at Ludlow, in going over a grassfield, my dog flushed a Corn-Crake, which flew steadily for a short distance and then dropped among the grass. Desirous of watching its movements, I hurried towards the spot where it had alighted, when I saw it stealing through the grass with the stealthiness and rapidity of a mouse, ever and anon raising its head to see the extent of the danger. Motioning the dog to stay behind, I crept cautiously to the spot; and as I drew near it, was surprised to see no attempt at escape. Having reached the place, I carefully examined the ground for some distance round, but could find nothing. I was just on the point of giving up the search, thinking that the bird had stolen off without my notice, when my attention was attracted by what appeared to me to be a clod of earth lying on the ground among the grass. On stooping down, I was surprised to find the object of my search apparently lifeless. I took it up: the head and legs dropped; to all appearance the bird was quite dead; but, being well acquainted with the habits of birds, I immediately detected the imposition; so, placing the bird upon the ground, I retired to a short distance, under cover of the trunk of a large tree. I had not remained there long, before I saw the cunning bird gently move; then, suddenly starting to its legs, it ran a short distance, took wing, and soon disappeared over an adjoining hedge. This is a striking instance of the deep cunning and sagacity which characterizes the habits of some birds." Several similar instances of these attempts at deception have appeared in the 'Zoologist,' in which it is stated that the bird, when taken in the hand, will appear perfectly dead, but if thrown into the air will fly away as well as ever.

The Land-Rail seldom employs its powers of flight, and, when it does, flies very slowly, with its legs hanging down, and speedily drops again into the first covert which seems likely to afford it shelter. Its food consists of worms, slugs, snails, various insects, some few vegetable matters, and seeds.

The nest, which is a very slight structure of dried plants, is generally placed in a hollow among corn, clover, or herbage of any kind. The eggs are of an elongated-oval form, from seven to ten in number. "They seldom vary," says Mr. Hewitson, "except in the size and frequency of the spots; some have the ground-colour of a warm red tint, with deep red-brown and purple blotches, while others are white, slightly tinted with blue, and fancifully streaked and spotted all over."

The sexes, which are alike in colour, may be thus described :-

The feathers of the upper surface are light yellowish brown, with an oblong spot of brownish black in the centre; a broad band over and behind the eye; throat and breast ash-grey; face and ear-coverts yellowish brown; flanks barred with light red and buff; wings light brown; bill and legs fleshy white; irides light hazel.

The female is somewhat smaller than the male, has the grey on the sides of the head less pure, and the usual colour of the wing mixed with darker brown.

The young are at first clothed with a long hair-like black down, which soon gives place to the plumage of the adult.

The Plate represents the two sexes of the natural size, and a brood of young birds about a fortnight old and beginning to assume the plumage of the adult. The plant is the Bladder Catchfly or Campion (Silene inflata). 


\section{$2 \mathrm{BHL}$ Biodiversity Heritage Library}

Gould, John. 1873. "Land-Rail or Corn Crake, Crex pratensis [PI. 87]." The birds of Great Britain 4, -. https://doi.org/10.5962/p.324041.

View This Item Online: https://www.biodiversitylibrary.org/item/221609

DOI: https://doi.org/10.5962/p.324041

Permalink: https://www.biodiversitylibrary.org/partpdf/324041

\section{Holding Institution}

Smithsonian Libraries

\section{Sponsored by}

Biodiversity Heritage Library

\section{Copyright \& Reuse}

Copyright Status: Public domain. The BHL considers that this work is no longer under copyright protection.

This document was created from content at the Biodiversity Heritage Library, the world's largest open access digital library for biodiversity literature and archives. Visit BHL at https://www.biodiversitylibrary.org. 